\title{
The BRICS Stocks Index as an Aggregate Indicator of Regional Economic Development
}

\author{
Mikhail V.Zharikov* \\ Financial University under \\ the Government of the Russian Federation \\ Moscow, Russian Federation
}

Received 22.10.2021, received in revised form 30.10.2021, accepted 10.11.2021

\begin{abstract}
The topic is time-relevant, since today there is a strong need to find indicators showing a development path for countries after the pandemics of 2020 in specific regions of the world. This paper makes an attempt to create an indicator that is different and more representative of the BRICS than the indexes already in existence. The BRICS index offered here is a capitalisation-weighted average of daily quotations for the listed stocks which dynamics highly correlate with each other. The purpose of developing such an index is to monitor a general growth pattern of the BRICS' economies and their corporations on the financial markets, both domestically and regionally, since they are at the core of the regions, they are in. The introduction of the BRICS index to the financial market can help increase investors' appetite for the assets. It will make it easier to analyze the stock markets of the BRICS as well. The significance of such a rating is that it may lay the foundation for working out a trading strategy to deal in the stocks of the BRICS companies to get optimal returns. The BRICS stocks index can also be an indicator of regional development for countries dependent on the BRICS, as well as the product of financial engineering which may help attract investors and other professionals working on the financial market to accumulate growth and recovery funds for the trouble countries of the region.
\end{abstract}

Keywords: BRICS, ratinomics, stock index, capitalisation-weighted industrial average indicator, investment portfolio, regional sustainable development, financial economy, financial innovations, financial engineering, economic and social crisis.

The article was written with the financial support of the Russian federal budget according to the assignment given to the Financial University.

Research area: world economy.

Citation: Zharikov, M.V. (2021). The BRICS stocks index as an aggregate indicator of regional economic development. J. Sib. Fed. Univ. Humanit. soc. sci., 14(12), 1920-1932. DOI: 10.17516/1997-1370-0870

\footnotetext{
(C) Siberian Federal University. All rights reserved

* Corresponding author E-mail address: michaelzharikoff@gmail.com ORCID: 0000-0002-2162-5056
} 


\title{
Индекс корпораций стран БРИКС как агрегированный индикатор регионального экономического развития
}

\author{
М.В.Жариков \\ Финансовый университет при Правительстве Российской Федеращии \\ Российская Федеращия, Москва
}

\begin{abstract}
Аннотация. Тема исследования актуальна в связи с тем, что в настоящее время сложилась необходимость разработки индикаторов, способных продемонстрировать траектории развития экономики и общества стран отдельных регионов после эпидемии 2020 г. В данной статье совершена попытка создать показатель, который отличается от аналогичных существующих индикаторов большей репрезентативностью социально-экономического развития стран БРИКС и стран регионов, в которых они играют роль локомотивов регионального развития. Предложенный индекс компаний стран БРИКС представляет собой средневзвешенную величину по уровню капитализации динамики котировок акций ведущих компаний, которые находятся в тесной корреляции друг с другом. Цель разработки такого индекса состоит в значимости мониторинга общей тенденции развития экономик стран БРИКС вкупе с их корпорациями на финансовых рынках как внутри, так и в регионе. Введение индекса компаний стран БРИКС в деятельность финансового рынка может способствовать привлечению инвесторов и дополнительных денежных средств для развития экономики и общества, фондов экономического оживления, особенно в период преодоления последствий коронакризиса 2020 г. Разработанный индекс позволит упростить анализ рынков ценных бумаг группировки стран, находящихся в разных регионах и принадлежащих к разным цивилизационно-культурным традициям в экономике и бизнесе. Значимость такого индекса заключается в том, что он может послужить основой разработки стратегии торговли акциями ведущих компаний стран БРИКС для оптимизации национального дохода и привлечения дополнительных средств для преодоления последствий коронакризиса. Индекс ведущих компаний стран БРИКС может рассматриваться и как индикатор регионального развития стран, находящихся в зависимости от БРИКС, а также в качестве продукта финансового инжиниринга, способствующего привлечению иностранного капитала на финансовом рынке.
\end{abstract}

Ключевые слова: страны БРИКС, рейтингономика, индекс ценных бумаг, средневзвешенный по уровню капитализации отраслевой индикатор, инвестиционный портфель, устойчивое региональное развитие, финансовая экономика, финансовые инновации, финансовый инжиниринг, социальноэкономический кризис.

Статья подготовлена по результатам исследований, выполненных за счет бюджетных средств по государственному заданию Финуниверситету.

Научная специальность: 08.00.14 - мировая экономика. 


\section{Introduction}

One of the identities of the new economy is the variety of ratings, rankings, graded financial products, indexes, indicators, etc. Recent data by Cao \& Wang (2020), Cheng (2019), Dong et al. (2019), among others, show that they have become an intrinsic and inherent part of the world capital markets and international finance, as well as social and economic development. World famous stocks indexes include Dow Jones (DJ30) of 30 most traded shares in the US, S\&P 500 (the index of 500 most traded companies in the US), British FTSE100, German DAX30, Japanese NIKKEI225, French CAC40, etc. In Russia we also have indexes such as RTS and MICEX. These indexes are simple averages of share prices of the biggest companies in a particular country.

Analysts like Alemany et al. (2020), Fu et al. (2020) and Gao at. el. 2020 and professionals, including Hou \& Li (2020) and $\mathrm{Hu}$ at el. (2020), use these indicators to monitor the international competitiveness of different countries of the world, build forecasts based on them and try to make predictions about future financial markets' performance, especially after the coronacrisis of 2020. However, these ratings are specifically country-oriented. The world, though, is a globalized system. Therefore, it needs cross-country ratings. They would be much better at reflecting the actual economic development across countries and regions. Countries badly need good ratings, because they could guarantee easy access to international loans, foreign capital markets as well as low cost of capital to help economic recovery. This is especially highlighted by Jain et al. (2020) and Janková \& Dostal (2020). Bad ratings lead to higher cost of capital and make it more difficult to apply for loans from the IMF or the World Bank during the government efforts in fighting the consequences of the pandemics. Today this is especially important during the coronavirus crisis, when countries face a lot of uncertainty and financial strain, which is proven by findings of Khan et al. (2020), Sabilla \& Kurniasih (2020) and Salisu \& Akanni (2020).

Many international organisations, nongovernment bodies, industry groups, associations, think-tanks, banks, consultancies and other related institutions predict that the 2020 s will be a period for economic, financial and political scientists across the globe to seek for potential indices to assess various economic stimulus plans introduced by governments to help the recovery. Younsi \& Bechtini (2020) say that many countries in the world will be running enormous budget deficits and government debt as a result of the economic, financial and health-care crisis. The 2020 s will be the era of unprecedented debt burden, financial tsunami, unemployment, unrecorded in the history of mankind.

Global decisions today are impossible without the far-reaching efforts of the BRICS to fight the disease, economic, financial and debt crises, climate change, to name the least. That was true a decade ago, and this is still valid these days when you read Zou et al. (2020), for example.

It is widely believed by, for example, Zheng et al. (2020) that ratings are still upon this day a byproduct of the information revolution. You can find confirmation that the information revolution changed market competition. It transformed the industrial architecture in many countries together with the rules of competition. It had created a competitive edge for many companies to outperform rivals. It laid the foundation for new types of enterprise, often within an existing niche of a single firm. Digitisation followed. Finacialisation, digitisation and financial engineering made ratings their instruments in measuring performance and efficiency. They started an era of completely new enterprises such as unicorns, fintechs, techfins and many other startups and ventures. Ratings neatly and seamlessly joined all these processes and made it unthinkable to imagine the world without the grades by Moody's, Standard and Poor's, Fitch and other household names.

The world financial crisis of 2008-2010 made economists question the methodology of how ratings, rankings, indexes, indicators and other measurements of economic activity are created. Therefore, they said that there was a need to rethink and review the old methodology and develop a new one which would have allowed to more accurately estimate the per- 
formance of companies, countries, regions and country groupings. The industry that deals with ratings came to be known as the economics of ratings, or ratinomics (Sagim, Reis, 2020).

Creating a rating is an extremely difficult and highly comprehensive, intellectual, smart process which is connected with a very high degree of risk, since, once published, it produces specific incentives for arbitragers, traders in commercial paper, debt obligations, government bonds, derivatives and commodities, etc. to make financial deals and investment decisions. In the world of huge debt caused by the coronavirus the wrongs must be minimal. So, ratings should be more specific, targetoriented, reliable, close in touch with the realty, credible and accurate.

\section{Data and methodology}

The creation of the BRICS corporate index involves a sequence of several specific iterations. A usual practice to calculate a stocks index since Dow Jones created his in 1928 was to take share prices on a given day and take an average of them. This way stock exchanges calculate DJ30 and NIKKEI, for example, until this day:

$$
\mathrm{I}=\sum_{i=1}^{n} \frac{\text { Price }_{i}}{n}
$$

where Price is the price of a share $i$ and $n$ is the number of shares in the sample.

However, the problem with such simplicity is that companies in a sample may have varying quantities of shares and weights in the industry. This may distort the very meaning of an index to show specifically the growth pattern in an economy. Generally, fewer shares may not portray the structure of ownership in a company's capital as a proportion of each partner in business. There is also a practice of disclosing part of shares in circulation. So only free floats appear in open trading. A company has a policy that rules free floats or how many shares actually go on to the market. Rarely, though, free floats exceed $50 \%$ of the capital. Since recent decades show that more and more big companies disclose the actual quantity of shares, it is worth taking a more precise measure of their impact on the market, industry and economy.
Thus, a capital-weighted stock index can be of a more theoretical and practical value to show the real distribution in the industry, namely:

$$
\mathrm{I}=I_{0} \frac{\sum \operatorname{Cap}_{i}+\operatorname{Cap}_{i+1}}{\sum \operatorname{Cap}_{0}+\operatorname{Cap}_{i+1}}
$$

where $I_{0}$ is the previous value of the index, the nominator is the total current capitalisation $\left(\mathrm{Cap}_{\mathrm{i}+1}\right)$ and the denominator is the previous total capitalisation $\left(\mathrm{Cap}_{0}\right)$. The approach also takes an account for a possible exclusion or inclusion of a company from or in the index, because during the research we excluded some companies to better understand the impact on the economy. Thus, to make an adjustment in the formula, there is no previous capitalisation value, namely:

$$
\mathrm{I}=I_{0} \frac{\sum C a p_{i}}{\sum \operatorname{Cap}_{0}+\operatorname{Cap}_{i+1}}
$$

\section{Approach to working out the BRICS corporate index}

First of all, the author delivered a list of 104 biggest and most promising companies of the BRICS in 2019, one of the best years for the BRICS' stocks in the second decade of the $21^{\text {st }}$ century. We decided to take data from 2019 because 2020 had serious fluctuations which make it impossible to trustworthy estimate the real impact of the index on the economy. Secondly, the author combined the technical analysis of individual companies of the BRICS with the general or fundamental analysis of a specific industry. Thirdly, to better understand the growth patterns of the BRICS shares represented by the index, the author calculated the correlation between their dynamics.

Once the author created the representative collection of the most correlated BRICS stocks, he took the calculated coefficients and put them into a hierarchical matrix (cluster plot) using the Seaborn package for Python. He then placed the correlation coefficients vertically and horizontally in the matrix.

\section{The hierarchical cluster plot (matrix) of the BRICS company stocks}

Fig. 1 shows the short representation of the cluster plot developed initially. It shows the 
in-country and inter-country correlation coefficients of the BRICS corporate stocks dynamics. In-country correlation coefficients stand for the stocks' combinations of only one of the countries, for example, Brazil or Russia. Intercountry correlation coefficients mean crosscountry stocks' combinations, for example, between Brazilian stocks and Russian stocks, or Brazilian stocks and Indian stocks, etc. The total number of correlation combinations in the matrix equals to as many stocks pairs as one can possibly find excluding the same-name stocks' combinations.

Thus, the 19 Brazilian companies picked up for the BRICS corporate index made 170 correlation combinations. Of these, 30 combinations, or $21.6 \%$, had correlation coefficients of more than 0.7 . 58 combinations, or $41.7 \%$, had correlation coefficients varying between 0.4 and 0.6. And, finally, 51 combinations, or $36.1 \%$ had weak correlation coefficients of between 0.0 and 0.3 . The remaining combinations had reverse correlations, i. e., their correlation coefficients were negative. Of all the incountry correlations, the Indian stocks combinations had the highest correlation coefficients. Here, $36 \%$ of all coefficients had correlations of more than 0.7 .

It is quite understandable that the intercountry corporate stocks' dynamics correlated less than the in-country ones because the matrix was dealing with the companies from five different countries. Of the cross-country stocks' combinations, the correlation was the highest in case of a China-India component where over $18 \%$ of the coefficients (or 168 combinations of the 918 positively correlated) exceeded 0.7. Second went the Russia-Brazil component where about $11 \%$ of the coefficients, or 35 units out of 323 postings in the matrix had the strongest correlation. In the rest of the inter-country stocks' combinations observed, the number of the positions with the highest degree of correlation was less than $10 \%$. Since the general collection of the BRICS stocks contained the combinations with negative correlation, the estimation power of the BRICS index got weaker and less representative of the grouping. To improve it we needed to reduce the number of companies from the initial aggregate collection. Therefore, at the next stage of the BRICS index's creation it was wise to consider the stocks correlation combinations of only the companies whose correlation coefficients exceeded 0.5. In the matrix built they made up 74 in number out of the initial 104 (Fig. 1).

Fig. 2 shows the dynamics of the BRICS stocks index. The technical analysis of the dynamics shows that during the period in question the most favourable moments to buy the shares of the BRICS companies from the general collection were as follows: January 4th and 23rd, March 9th, April 19th, May 5th, July 6th, October 2nd and 27th and December 6th. As we see, most of the dates fell on a month's beginning with some exceptions when the good moments to buy the BRICS stocks moved closer to a month's end. The most favourable moments to close the positions in the BRICS stocks were as follows: January 22nd, February 22nd, March 20th, April 28th, June 6th, August 8th, September 18th, November 22nd, December 26th. Fig. 1 demonstrates that in most cases the best moments to close the positions fell on a mid or end of a month.

\section{Methodological hypothesis}

The hypothesis is that there must be some kind of an indicator showing a general growth path of the BRICS stocks. The narrower collection of the companies with a higher degree of correlation is more representative of the grouping to identify a universal trajectory of the BRICS companies' performance and the performance of its economy in general, although, of course, there are deviations of some of the stocks' dynamics from the general growth pattern both up and down.

The dates considered to be the best to buy and sell the BRICS stocks are the moments when it is most profitable to trade in all BRICS stocks. More specifically and accurately, an investor should choose the timing to buy or sell the BRICS stocks based on the analysis of each individual company. Despite the visible efficiency of the BRICS stocks index, the actual best dates to buy or sell the stocks may not coincide with the suggested ones, since the BRICS index only shows a general direction 


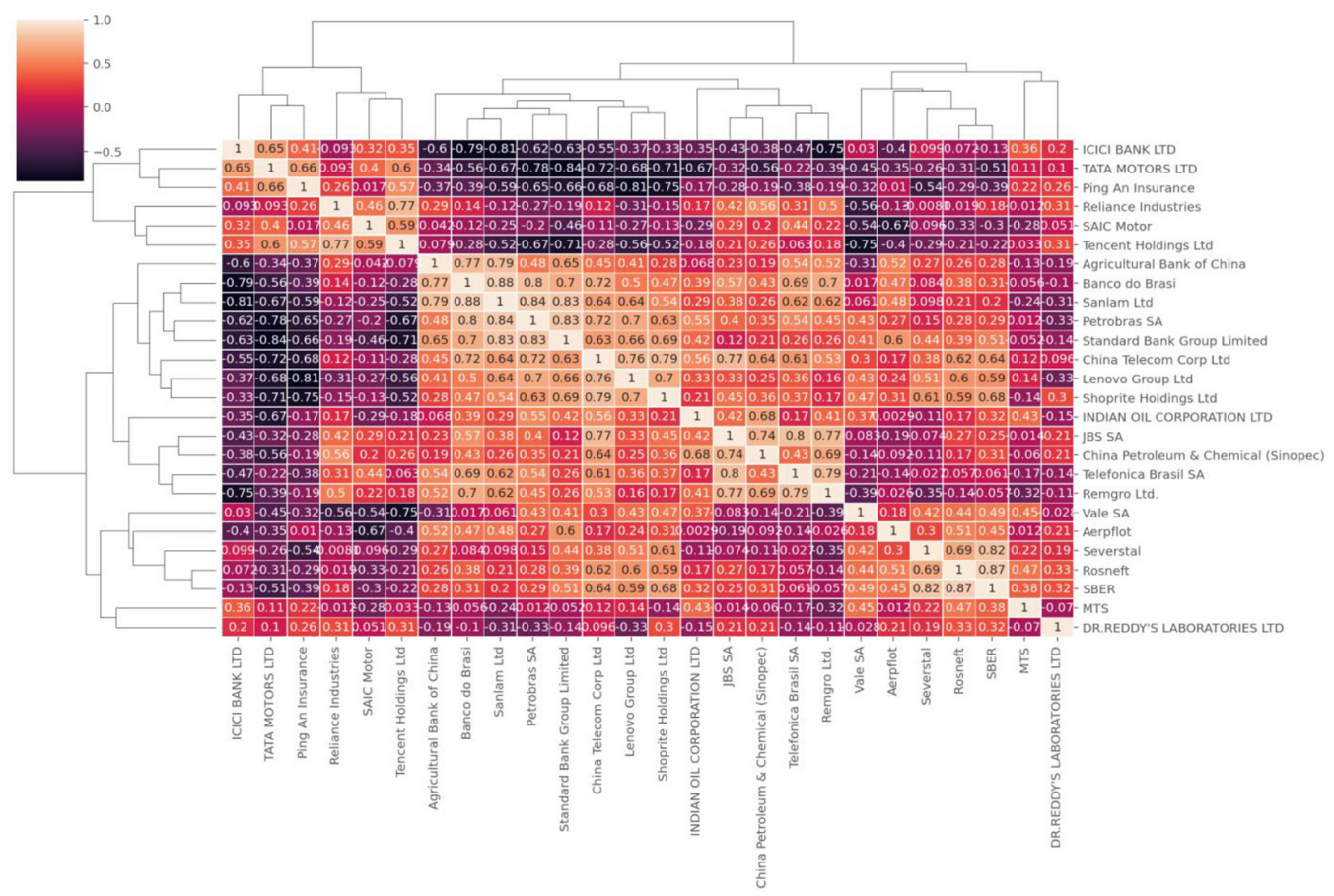

Fig. 1. The hierarchical cluster plot of BRICS corporate shares' quotations dynamics correlation. Source: compiled by the author based on the data of the BRICS foreign exchange markets, NYSE, Euronext

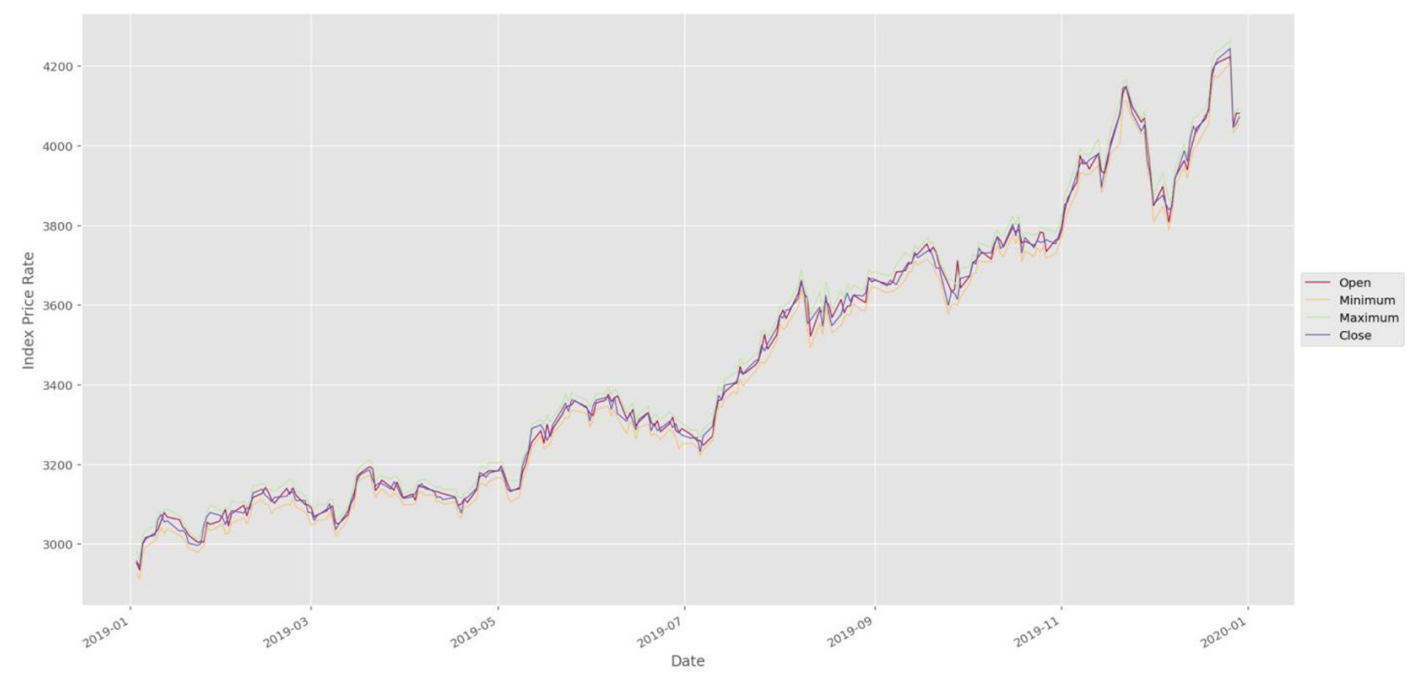

Fig. 2. Daily dynamics of the BRICS corporate index's changes, 2019.

Source: compiled by the author based on the data of the BRICS foreign exchange markets, NYSE, Euronext 
of the stocks' movements and does not give a $100 \%$ guarantee that certain occasions really occur.

Although the BRICS stocks have different prices, face values and issuance volumes, the BRICS index must show a general or universal trend. Therefore, the constructed index must have a sort of a statistical weight, a basic measure or a unit of reference which represents all securities. This unit or measure can be either the quantity of shares being traded on the stock market or, which is more adequate and representative, the capitalisation of the selected companies picked up for the analysis.

Capitalisation is a superior indicator compared to the number of stocks traded since it generalizes trading activity and transactions expressed in national currencies, especially when the stocks are traded exclusively on the stock markets of the BRICS. If the trades take place on the European stock markets, the quotations appear in the euros. In most other cases the trades go in US dollars, especially when the BRICS's shares come as American depositary receipts on the market. Since we gathered the statistics about the BRICS stocks for our study using various stock market databases and different trading systems, many BRICS stocks may end up valued in various currencies. The currency diversity, however, should not disturb the technical analysis of the BRICS stocks. This diversity makes it hard to produce a universal indicator, i. e., the BRICS stocks index. Therefore, to achieve the paper's goal, it was necessary to convert the face value of the BRICS stocks expressed in currencies other than US dollars in US dollars, excluding the stocks already expressed in US dollars.

\section{The simulation of the BRICS corporate index}

During the given year, the total number of same-company capitalisation values must be equal to the four prices of a stock on each trading day multiplied by the number of working days in the year. Some authors like Kim (2019) used a linear function. The underlying research makes use of a polynomial one. Four capitalisation values of the BRICS stocks measured over the entire year give out the dynamics of the index. The dynamics show the average price of the BRICS selected stocks weighted by the amount of total capitalisation. The BRICS stocks index dynamics can also appear as a mathematical equation or a system of equations with four independent variables, namely (Formulas $4 a-4 d)$ :

$$
\begin{aligned}
& y=-9 e-08 x^{4}+2 e-05 x^{3}- \\
& -0,0015 x^{2}+0,0343 x+16,04 \\
& y=-8 \mathrm{E}-07 x^{4}+0,0002 x^{3}- \\
& -0,0171 x^{2}+0,6039 x+71,675 \\
& y=-3 \mathrm{E}-07 x^{4}+5 \mathrm{E}-05 x^{3}- \\
& -0,0051 x^{2}+0,2003 x+65,544 \\
& y=-2 \mathrm{E}-08 x^{4}+3 \mathrm{E}-06 x^{3}- \\
& -0,0003 x^{2}+0,0089 x+6,4885
\end{aligned}
$$

The four independent variables in the system of equations above describe open, minimum, maximum and close prices' dynamics. The equation of the BRICS stocks index dynamics is derived by means of simple arithmetic addition of the four equations. The four equations have homogenous members to sum up, and the result is a single composite equation that shows the dynamics of the BRICS companies' stocks, namely:

$$
\begin{aligned}
& y=-0,0000012 x^{4}+0,00027 x^{3}- \\
& -0,024 x^{2}+0,8474 x+157,7475
\end{aligned}
$$

To make the BRICS stocks index look more like the Dow Jones or S\&P 500, it is necessary to convert it into regular basis points. To do that, we are to take a moment in time of interest for us, replace $\mathrm{x}$ by that in the equation and multiply the result by 1,000 . Since a mathematical equation usually has an angle with a specific degree of inclination, so does the equation of the BRICS stock index. Economically, the greater this inclination is, the more optimistic can an investor be about the future performance of the BRICS stocks.

We already said above that there was no real stock exchange in existence to trade in the stocks listed in the BRICS index. However, once created in the virtual environment, the BRICS stocks index might be an important benchmark of the virtual stock market of the BRICS. The specific feature of this shared 
stock market is that it may work in the virtual space and time with no territorial or timely peg. The BRICS stocks index is an indicator showing the general growth pattern of the selected stocks and their market value.

The projected market value of the BRICS stocks listed in the index, once introduced to the virtual stock market, could have amounted to 4.2 trillion dollars. The equation of the BRICS stocks index dynamics may also show a prospective growth pattern of the stocks listed in it as well as the capitalisation of the virtual shared market of the BRICS stocks. Since the equation of the BRICS stocks index dynamics is positively inclined or has an increasing growth pattern, the prognosis about its future performance based on it is quite optimistic. The point here would be only about the degree of being optimistic about the BRICS stocks index dynamics, i. e., it is going to vary from the least optimistic to the most optimistic one. According to the least optimistic prognosis, in a year's time period, the capitalisation of the BRICS stocks listed in the index could amount to 5.2 trillion dollars, which was almost a $24 \%$ increase compared to the initial valuation. According to the model developed here, during the period in question the average price level of the BRICS stocks index would have varied between 4,063 and 5,248 basis points.

\section{The correlation of economic growth and the BRICS corporate stocks' dynamics}

Although the coronavirus crisis hit hard most economies in the world, including the BRICS, the IMF projects sustainable economic growth in the BRICS later in the 2020s. The dynamics of economic growth in the BRICS and the BRICS stocks index movements are shown in Fig. 3.

It is clear that the contours of the BRICS stocks index curve very much liken the contours of the economic growth curves of the five countries. Most evidently, we can observe this by the look of the BRICS stocks index curve and the curves of economic growth in India and Russia. These curves have minimums and

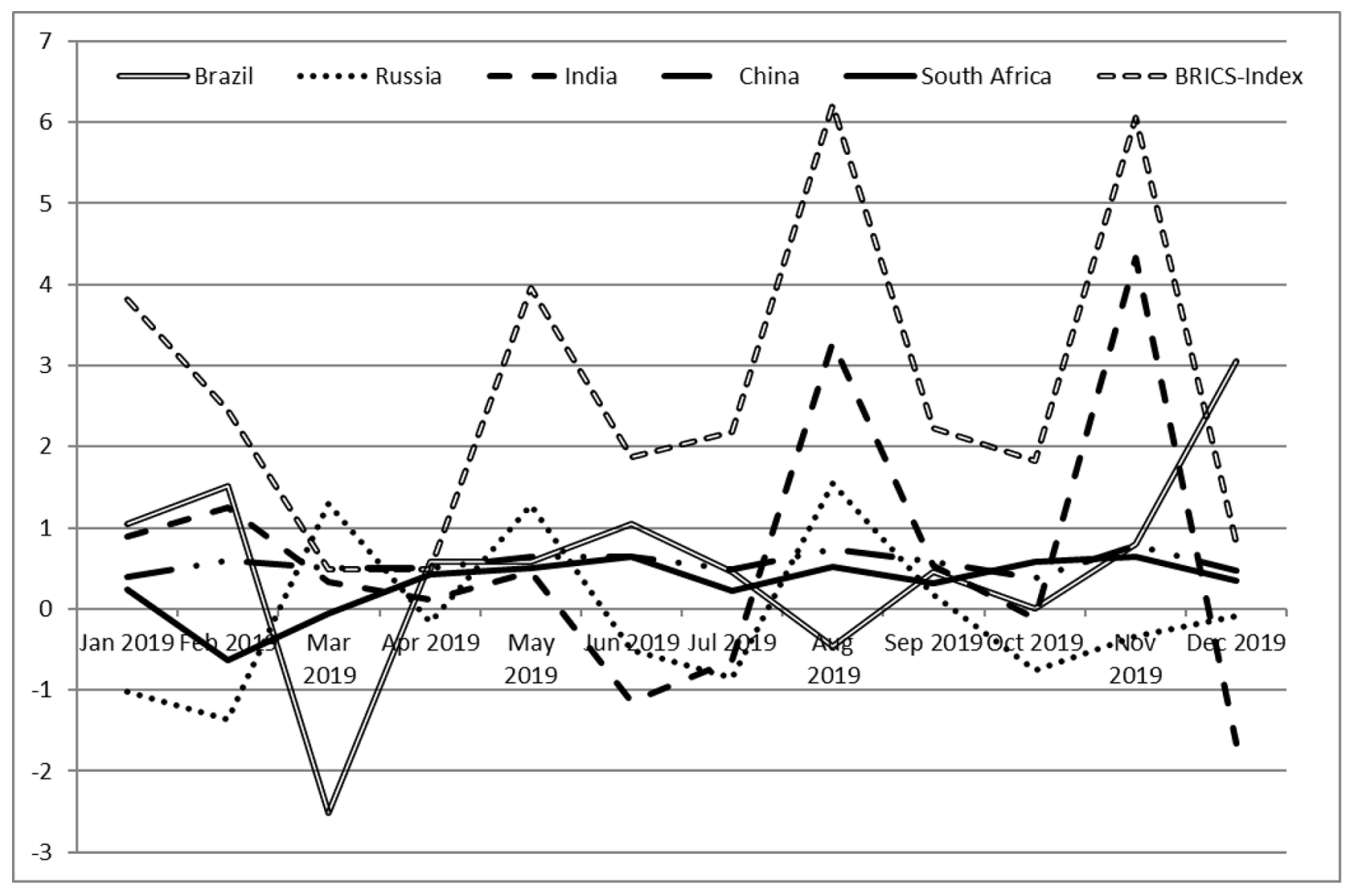

Fig. 3. The GDP growth dynamics and the BRICS corporate index dynamics, 2019.

Source: compiled by the author based on the data of the IMF, the BRICS foreign exchange markets, NYSE, and Euronext 
maximums which happen in the same time periods.

We can also confirm the hypothesis by the correlation analysis of the monthly dynamics of GDP growth rates of the BRICS and the BRICS stocks index. According our analysis, the BRICS GDP growth rates and the BRICS stocks index correlated in most observations. In some of the observations the correlation was extremely strong, exceeding 0.7 .

\section{The results of the BRICS stocks index}

The practical significance of the assumptions expressed in the paper comes down to the economic benefit received from successful performance of a would-be investment portfolio comprised of the BRICS stocks. To determine whether it is worth introducing the BRICS stocks index to the practice of stock markets, it is best to design a would-be investment portfolio of some of the BRICS stocks. Basically, an investment portfolio consists of the bestperforming stocks on the market. Usually, it comes into being early in a particular year and finishes its activities by the year's end. For example, the investment portfolio of the BRICS stocks as proposed by the paper was established on January 12th. We hypothesized that an investor spent 1 million dollars on each of the stocks he/she had picked up from the stocks listed in the BRICS stocks index. On December 26th, they closed the positions and liquidated the portfolio. Thus, they acquired a number of the stocks of the BRICS index and later took profit.

To assess the performance of the BRICS stocks index, we proposed the comparative analysis of two different investment portfolios (Table 1). Portfolio A, for example, consisted of stocks chosen on the basis of the technical analysis of each individual stock listed in the BRICS index. This portfolio started its life early in the year and ended its activity by the moment when the current price reached a supposed maximum. The maximum did not have to necessarily coincide with the day and time chosen according to the dynamics pattern of the BRICS stocks index. Portfolio B began working on the day of the year which according to the index was considered the most convenient. Unlike Portfolio A, we liquidated Portfolio B later on the day, also suggested by the BRICS stocks index dynamics. Clearly, Portfolio A turned with more profit than Portfolio B, since all stocks' quotations for the year had been known in advance. In reality, investors never know this, and they are difficult to predict. Thus, it is precisely because of this that the BRICS stocks index has such practical significance, for it may help identify the moments of time to create and liquidate a portfolio of assets which would ensure the optimal rate of profit and the optimal performance of the stocks chosen.

According to the author's calculations, the optimal profitability of the investment portfolio comprised of the stocks listed in the BRICS index could have amounted to about 19-20\% p. a. in 2019. The proposed investment portfolio was optimal and well-structured when filled up with up to $15 \%$ of the Russian and Brazilian stocks each, $40 \%$ of the Indian stocks, $23 \%$ of Chinese and about $8 \%$ of South African ones.

Table 1. Designing the investment portfolio of the BRICS stocks

\begin{tabular}{|l|c|c|c|c|c|c|c|}
\hline \multicolumn{2}{|c|}{ Indicatior, million dollars } & Brazil & Russia & India & China & SAR & BRICS \\
\hline \multicolumn{2}{|l|}{\begin{tabular}{l} 
Initial investment \\
\hline A country's share, $\%$
\end{tabular}} & 11.0 & 13.0 & 28.0 & 16.0 & 6.0 & 74.0 \\
\hline \multicolumn{2}{|l|}{ The maximum profit } & 3.7 & 2.2 & 11.9 & 7.5 & 2.6 & 27.9 \\
\hline $\begin{array}{l}\text { The BRICS portfolio on } \\
\text { specified dates }\end{array}$ & 18.09 .2019 & 2.3 & 0.1 & 6.4 & 3.6 & 0.1 & 12.5 \\
\cline { 2 - 9 } & 22.11 .2019 & 1.5 & -0.1 & 7.3 & 5.1 & 0.5 & 14.3 \\
\cline { 2 - 9 } & 26.12 .2019 & 1.3 & -0.6 & 8.1 & 4.9 & 1.0 & 14.8 \\
\hline
\end{tabular}

Source: compiled by the author based on the data of BRICS foreign exchange markets. 
Table 2. The market value of the BRICS stocks index companies, 2019

\begin{tabular}{|c|c|c|c|c|c|}
\hline Country & $\begin{array}{c}\text { Market } \\
\text { value, year start, } \\
\text { billion dollars }\end{array}$ & Country share,\% & $\begin{array}{c}\text { Market } \\
\text { value, year end, } \\
\text { billion dollars }\end{array}$ & Country share, \% & $\begin{array}{c}\text { Market value } \\
\text { growth, } \%\end{array}$ \\
\hline Brazil & 173.1 & 7.4 & 199.1 & 6.5 & 13.1 \\
\hline Russia & 339.3 & 14.5 & 320.6 & 10.4 & -5.8 \\
\hline India & 638.9 & 27.3 & 859.1 & 27.9 & 25.6 \\
\hline China & 1136.5 & 48.6 & 1634.7 & 53.0 & 30.5 \\
\hline South Africa & 50.1 & 2.1 & 70.5 & 2.3 & 29.0 \\
\hline BRICS & 2337.9 & 100.0 & 3083.9 & 100.0 & 24.2 \\
\hline
\end{tabular}

Source: compiled by the author based on the data of BRICS foreign exchange markets.

The analysis of the BRICS stocks index's dynamics showed that 2019 was not a very good year to buy the stocks of the Russian companies. Of the three optimal moments chosen for that purpose and shown in Table 2 only one was good enough to buy the stocks of Russian companies, and even that one deal would have generated only about 30 thousand dollars. The two other moments to buy the stocks of the Russian companies would have not turned with profit at all. The falling profitability of the Russian companies' stocks was mainly due to the international sanctions and decreasing demand on part of the investors operating on the Moscow Exchange. This resulted in the decrease in the capitalisation of the Russian companies listed in the BRICS stocks index by almost 20 billion dollars.

\section{The regional application of the BRICS stocks index}

Right at the start we said each of the BRICS is the economic and industrial core in a region. In case of Brazil the region would be MERCOSUR, in case of Russia - the Commonwealth of Independent States and Eurasian Economic Union, India - South Asian Association of Regional Cooperation, China Asia-Pacific, and South Africa - South African Common Currency Area. Each country in the regions in question heavily depends on what happens in the economies of the BRICS. Even a minor change in the stock markets of the BRICS may lead to dramatic changes in the neighborhood. For example, an importer in MERCOSUR would find it much better to buy goods in Brazil when the exchange rate of the Brazilian real traded lower in the foreignexchange market than at the central bank. Then a national currency in the region would buy more reais and hence more goods from Brazil. In the case of the research that means the regional economy would drive higher the share prices of Brazilian companies and thus the Brazilian component of the BRICS index. Consequently, if the real traded lower on the foreign exchange markets of Venezuela, Uruguay, Paraguay and Argentina than at the central banks of the region, then lower quantity of national currency would buy reals. The importer and the consumer in the region would benefit. Venezuela, Uruguay, Paraguay and Argentina may find it interesting to acquire the shares of the Brazilian companies as well and the Brazilian currency to finance more imports from Brazil or to accumulate foreign-exchange reserves. In return, Brazil would get its own currency from the countries of region bypassing the US dollar. This may also drive the economic growth not only in Brazil, but also in the region.

In case of Russia the region also takes an important role in economic development. Moscow Exchange is the place to trade Belarus rubles and Kazakh tenge for the Russian ruble. Though, the trade volume is not great, it is a very significant element of economic growth in the region, because again, national currencies can buy goods and services in the countries of the region and stimulate corporate growth. Cross-border trade in the region in national currencies is part of a more ambitious goal for ever closer union in the Eurasian Economic 
Union, because exporters and importers may use national currencies more frequently and trade them more freely on the Moscow Exchange, driving the value of the Russian ruble and thus the Russian component in the BRICS index.

India has also a region to exert economic power. Counties such as Bhutan and Bangladesh heavily depend on its economic performance and buy many goods from India. Both countries of the region use Indian rupees as a currency at a fixed exchange rate to the national currencies. It means no foreign-exchange-rate volatility to profit by. However, more imports from India to the countries of the region traded for rupees may drive the share prices of Indian companies and thus the Indian component in the BRICS index.

China is more active in Asia than any other country of the region. Therefore, there can be no talk of an integration grouping for China to be of most importance to deal with. So, we prefer taking Asia-Pacific as a region of economic leadership and development in case of China. Changes in China's financial markets immediately send shock waves across far and wide. Even Australia and New Zealand feel decision taken in China for example on steel and coal production, gold purchase and semiconductor exports. In closer proximity, Russian Far East and Russia as a whole depend much on cooperation with China. Russian regions on the border to China benefit much from trade deals in national currencies. Russian rubles and Chinese yuan trade on the Moscow Exchange and in the China Foreign Exchange Trade System in Shanghai. Companies of both countries may benefit much if they exchange goods in national currencies away from the US dollar. This will be a stimulating factor for businesses and translate in more investor interest in the corporate stocks. Here both Russian and Chinese components would add much power to the BRICS index to show economic development in the region.

Finally, South Africa is at the core of the South African Common Currency Area. Lesotho, Namibia and Swaziland joined the area to convert their currencies for South African rands for better economic cooperation and development in the region. The Johannesburg Stock Exchange is the powerhouse for all stock treaded in Africa. The African component is a very important addition to the BRICS stocks index, especially from the regional standpoint. Any change in this component would be an indication of a general pattern for economic development in the region as well. If Botswana joins the monetary union, it will also benefit from direct trade in national currencies. South African companies are leading businesses in regional economy. Their stocks are very popular with investors from other African countries and abroad. Their performance also appears in the BRICS index dynamics. On the balance, the BRICS stocks index may become a very important indicator for the countries involved and the countries in close proximity in terms of regional economic development and international cooperation, which seems quite important, especially in the period when the world tries to go through the period of the corona-crisis and return to normality.

\section{Conclusion}

With some of the weaknesses in mind, the BRICS stocks index may still come as a useful instrument to understand the workings of the grouping's industry and countries of the region. For example, it may help reveal the character of inclusive development of the economies, member nations of the regional integration agreements. The research has found that in many observations the BRICS stocks index correlated with the GDP growth dynamics of each country of the grouping. It means that in fact it is an indication showing a certain degree of inclusiveness of the BRICS within itself. This inclusiveness and the ability to develop side by side are perhaps what helped the BRICS gain power in the world economy since the start of the $21^{\text {st }}$ century. There is a real economic basis behind this inclusiveness which in this case means that the BRICS may make collective decisions on major issues on the agenda for the world during regular summits to deal with global challenges such as the coronavirus crisis. Also, the identified correlation of the stocks listed in the index leads to the conclusion that in terms of inclusive development 
and contrary to a currently wide-spread idea of deglobalisation, the economic model of the BRICS may become a new form of integration and economic cooperation in the new world economy and an established, holistic grouping comparable to the model of the newly industrializing nations, which also matters much for the economy of the region.

\section{References}

Alemany, N., Arago, V., Salvador, E. (2020). Lead-lag relationship between spot and futures stock indexes: Intraday data and regime-switching models. In International Review of Economics and Finance, 68 (7), 269-280. https://doi.org/10.1016/j.iref.2020.03.009.

Cao, J. S., Wang, J. H. (2020). Exploration of stock index change prediction model based on the combination of principal component analysis and artificial neural network. In Soft Computing, 24 (11): 7851-7860. https://doi.org/10.1007/s00500-019-03918-3.

Cheng, T. J. (2019). A Multifactor Fuzzy Time-Series Fitting Model for Forecasting the Stock Index. In Symmetry, 11 (12), 1474-1475. https://doi.org/10.3390/sym11121474.

Dong, X., Ma, R., Li H. (2019). Stock index pegging and extreme markets. In International Review of Financial Analysis, 64 (7), 13-21. https://doi.org/10.1016/j.irfa.2019.04.012.

$\mathrm{Fu}$, Y., Su, Z., Xu, B., Zhou, Y. (2020). Forecasting Stock Index Futures Intraday Returns: Functional Time Series Model. In Journal of Advances in Computer Intelligent Information, 24 (3), 265-271. https://doi.org/10.20965/jaciii.2020.p0265.

Gao, P., Zhang, R., Yang, X. (2020). The Application of Stock Index Price Prediction with Neural Network. In Mathematical Computer Applications, 25, 53-55. https://doi.org/10.3390/mca25030053.

Hou, Y. (G.), Li, S. (2020). Volatility and skewness spillover between stock index and stock index futures markets during a crash period: new evidence from China. In International Review of Economics and Finance, 66 (3), 166-188. https://doi.org/10.1016/j.iref.2019.11.003.

Hu, J. Q., Wang, T. X., Hu, W. W., Tong, J. (2020). The impact of trading restrictions and margin requirements on stock index futures. In Journal of Futures Markets, 40 (7), 1176-1191. https://doi.org/10.1002/fut.22111.

Jain, T., Sehgal, S., Agrawal, R. (2020). Disruptive Innovations, Fundamental Strength and Stock Winners: Implications for Stock Index Revisions. In Vision-The Journal of Business Perspective, 24 (3), 356-370. https://doi.org/10.1177/0972262920928890.

Janková, Z., Dostal, P. (2020). Prediction of European Stock Indexes Using Neuro-Fuzzy Technique. In Trends Economics and Management, 35 (1), 45-57. https://doi.org/10.13164/trends.2020.35.45.

Khan, K., Zhao, H.W., Zhang, H., Yang, H. L., Haroon, M., Jahanger, A. (2020). The Impact of COVID-19 Pandemic on Stock Markets: An Empirical Analysis of World Major Stock Indices. In Journal of Asian Finance Economics and Business, 7 (7), 463-474. https://doi.org/10.13106/jafeb.2020.vol7.no7.463.

Kim, S. (2019). Examination of the Nonlinear Relationship between Stock Index and Oil Prices. In Korean Journal of Financial Engineering, 18 (3), 107-129. https://doi.org/10.35527/kfedoi.2019.18.3.005.

Sabilla, A. R., Kurniasih A. (2020). The Effect of Macroeconomics on Stock Index. In International Journal of Economics and Management Studies, 7 (3), 85-92. https://doi.org/10.14445/23939125/IJEMSV7I3P113.

Sagim, K., Reis, S. G. (2020). The Effects of Independent Audit Opinion on Stock Returns: Case of Borsa Istanbul. In Journal of Economics and Administrative Sciences, 15 (2), 649-662.

Salisu, A. A., Akanni, L. O. (2020). Constructing a Global Fear Index for the COVID-19 Pandemic. In Emerging Markets Finance and Trade, 56 (10), 2310-2331. https://doi.org/10.1080/1540496X.2020.1785424.

Younsi, M., Bechtini, M. (2020). Economic Growth, Financial Development, and Income Inequality in BRICS Countries: Does Kuznets' Inverted U-Shaped Curve Exist? In Journal of the Knowledge Economy, 11 (2), 721-742. https://doi.org/10.1007/s13132-018-0569-2.

Zheng, Y. X., Zhang, Y. H., Lu, X. H. (2020). On the Volatility of High Frequency Stock Index Based on SV Model of MCMC. In Springer Proceedings in Mathematics and Statistics, 302, 271-278. https://doi. org/10.1007/978-981-15-0422-8_23. 
Zou, P., Wang, Q., Xie, J. H., Zhou, C. X. (2020). Does doing good lead to doing better in emerging markets? Stock market responses to the SRI index announcements in Brazil, China, and South Africa. In Journal of the Academy of Marketing Science, 48 (5), 966-986. https://doi.org/10.1007/s11747-01900651-z. 